\title{
Tradition and Perspectives of Arab Herbal Medicine: A Review
}

\author{
Bashar Saad $^{1,2}$, Hassan Azaizeh ${ }^{1}$ and Omar Said ${ }^{1}$ \\ ${ }^{1}$ The Galilee Society R\&D Center (Affiliated with Haifa University), PO Box 437, Shefa-Amr 20200, Israel and \\ ${ }^{2}$ Faculty of Allied Medical Sciences, Arab American University, PO Box 240, Jenin, Palestine
}

\begin{abstract}
Complementary and Alternative Medicine (CAM), including herbal medicine, are popular in the general population worldwide. Parallel to the increasing interest in 'modern' CAM therapies and the historical importance of Arab medicine, there is also a similar trend in research activities dealing with the efficacy and safety of medicinal plants in our region. Historical and current studies and surveys indicate that the Eastern region of the Mediterranean has been distinguished throughout the generations with a rich inventory of natural medicinal herbs. It is well documented that indigenous Arab medicine has contributed greatly to the development of modern medicine in Europe and remains one of the closest forms of original European medicine. The rapid increase in consumption of herbal remedies worldwide has been stimulated by several factors, including the notion that all herbal products are safe and effective. This article presents a systematic review on traditional Arab medicine including historical background, medical innovations introduced by Arab physicians in the field of safety and efficacy of herbal medicine and a state-of-the-art description of traditional Arab herbal medicine in the Mediterranean region.
\end{abstract}

Keywords: Arab herbal medicine - in vitro and in vivo complementary medicine - toxicity and efficacy

\section{Introduction}

\section{An Historical Background}

Herbal remedies and alternative medicines are used throughout the world and in the past herbs often represented the original sources of most drugs (1-3). The plant kingdom has provided an endless source of medicinal plants first used in their crude forms as herbal teas, syrups, infusions, ointments, liniments and powders. Evidence of use of herbal remedies goes back some 60000 years to a burial site in a cave in northern Iraq, which was uncovered in 1960 (4). An analysis of the soil around the human bones revealed extraordinary quantities of plant pollen of eight species. Seven of these are medicinal plants and still used throughout the herbal world (5). With the development of chemistry and Western medicine, the active substances of many species have been isolated and in some cases duplicated in the form of synthetic drugs (6). Nevertheless, the synthetic preparation of some drugs is either

For reprints and all correspondence: Prof. Dr Bashar Saad, The Galilee Society R\&D Center, PO Box 437, Shefa-Amr 20200, Israel. Tel: +972-4-9504523/4; Fax: +972-4-9504525; E-mail: bsaad@gal-soc.org, bsaad@aauj.edu unknown or economically impractical. For this reason, scientists continue to search for and test little-known plants and conserve those whose medicinal properties have become crucial in the fight against diseases. Herbal-derived substances remain the basis for a large proportion of the commercial medications used today for the treatment of heart disease, high blood pressure, pain, asthma and other illnesses. For example, ephedra is an herb used in traditional Chinese medicine for more than 2000 years to treat asthma and other respiratory problems. Ephedrine, the active ingredient in ephedra, is used in the commercial pharmaceutical preparations for the relief of asthma symptoms and other respiratory problems. It helps the patient to breathe more easily. Today a great number of modern drugs are still derived from natural sources, and $\sim 25 \%$ of all prescriptions contain one or more active ingredients from plants. Herbal medicine can be broadly classified into four basic systems as follows: Traditional Chinese Herbalism, Ayurvedic Herbalism, Western Herbalism, which originally came from Greece and Rome to Europe and then spread to North and South America, and Arab traditional medicine, which forms the basis for alternative and herbal medicine in use today. The present review will discuss the status of traditional Arab medicine, and in particular herbal medicine,

(C) The Author (2005). Published by Oxford University Press. All rights reserved.

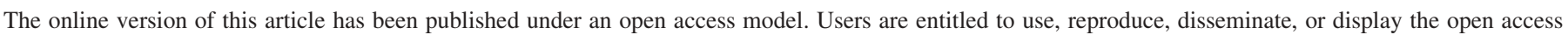

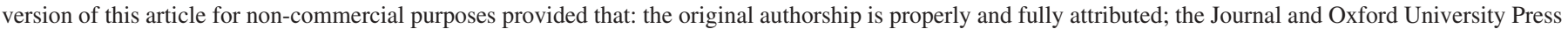

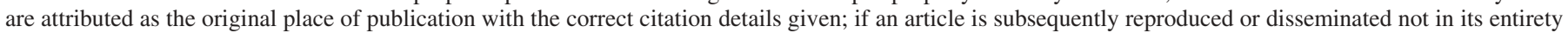
but only in part or as a derivative work this must be clearly indicated. For commercial re-use, please contact journals.permissions@oxfordjournals.org 
including their efficacy and toxicity in a geographic area that includes Syria, Palestine, Lebanon, Israel and Jordan, which used to be called Bilad el-Sham (7).

\section{The Development of Arab Medicine}

The history of Arab medicine can be conveniently divided into three phases, characterized briefly as follows: Phase I, Greek into Arab; Phase II, Arab; and Phase III, Arab into Latin. The first phase was the period of translation of Greek scientific and philosophical works into Arabic. This started in the eighth century AC when Islam covered nearly two-thirds of the known world and contacts with the West were already established through Byzantium, Spain and Sicily. The Khalifs in Baghdad became aware of what was to be learned from Greek science, and in the reign of al-Ma'mun an institution was founded for this purpose, 'The House of Wisdom'. The most famous of all the translators was Hunayn Ibn-Is'haq, a Nestorian Christian who became court physician to the Khalif alMutawakkil. He and his team translated a large number of medical works of Hippocrates and Galen, as well as philosophical works by Plato and Aristotle and mathematical works of Euclid and Archimedes. Hospitals and medical schools flourished during that period, first in Baghdad and later in the main provincial cities. After the first period of translation, when the chief works of Galen and Hippocrates were made available in Arabic, Christians lost their monopoly of medicine and several Muslims reached such a stature in medical science that they stood far above their immediate predecessors and were roughly on a level with the greatest of the Greeks. Some notable scholars of the science of Arab medicine are as follows: Al Tabbari (838-870), Al Razi (Rhazes) (846-930), Al Zahrawi (930-1013), Avicenna (980-1037), Ibn Al Haitham (960-1040), Ibn Al Nafees (1213-1288) and Ibn Khaldun (1332-1395).

The third phase of Arab medicine started in the twelfth century when European scholars interested in science and philosophy came to appreciate how much they had to learn from the Arabs, and set about studying Arab works in these disciplines and translating the chief of them into Latin. Probably the most outstanding writer on medicine in Arabic was Ibn-Sina or Avicenna as he was called in the West (dated 1037). Like Al Razi, he wrote on many subjects and was accounted to have been greater as a philosopher than as a physician. Nevertheless, his vast 'Canon of Medicine' is rightly acclaimed as the 'culmination and masterpiece of Arab systematization'. It was translated into Latin in the twelfth century and continued to dominate the teaching of medicine in Europe at least until the end of the sixteenth century. There were 16 editions of it in the fifteenth century, one being in Hebrew, 20 editions in the sixteenth century and several more in the seventeenth century.

\section{Medical Innovations Introduced by Arab Physicians}

Medical innovations introduced by Arab (Muslim) physicians include discovery of the immune system and introduction of microbiological science $(8,9)$. Furthermore, Avicenna was the first to use ice to treat fever diseases and separate medicine from pharmacological science (this fact resulted in a huge development in pharmaceutical science), Arab physicians introduced the use of test animals $(9,10)$ and Arab physicians combined different sciences such as chemistry, medicine, pharmacology, agriculture and plant science in order to develop new aspects in their dealings with patients. In surgery, Al Zahrawi was the first to develop various surgical equipments and tools, some of which were unique to surgery for women $(8,9,11)$. Later on, Ibn Al Haitham improved eye surgery and studied the process of sight for the first time. Concerning herbal medicine, Arab physicians introduced many new aspects and upgraded the knowledge about herbs and their potential medical efficacy and safety. In brief:

(i) Arab chemists such as Ibn Hayan and others were able to extract different anesthetic compounds from local herbs for local or general anesthetization. Among the herbs used for extractions were Hyoscyamous aureus, Opium and Cannabis sativa.

(ii) In Andalusia (Spain), Arab physicians, botanists and pharmacologists led by Ibn AlBitar were able to introduce around 350 new plant species as medicinal herbs for treating human diseases (Ibn AlBitar, 1874).

(iii) Abu AlAbbas and other herbalists published several books and dictionaries on the use of medicinal plants describing each plant species, the plant parts used, the preparation procedure for each remedy and the treatment procedure of certain diseases $(8,9,12,13)$.

(iv) Avicenna published several books such as 'Alkanoon Fi Altib' (The roles of Medicine) in addition to Rhazes book 'AlHawy' (The Comprehensive), which were translated into different languages $(10,11)$. These two books were the main literature in medicine a few centuries ago and are still in use in different libraries in Europe.

(v) One of the main niches of Arab medicine in the fourteenth century was Daoud AlAntaki, an Arab physician who lived in Egypt and used different herbs for treating patients; he also published a book on medicinal herbs summarizing the know-how of his predecessors.

\section{Safety of Herbal Remedies}

Parallel with the development of pharmacy and pharmacology in the Arab world, there was also a similar development in alchemy and toxicology. Origins of these developments date back to the Greeks and Indians as well as to the empiric knowledge of the indigenous population. Alchemy was commonly practiced during the ninth century and many works have been written on this art. One good example of an independent manual on toxicology is Kitab as-Sumum, in five volumes, attributed to Shanaq, the Indian. It was translated into Arabic by al-'Abbas bin Sa'id al-Jawhari for caliph al-Ma'mun (reigned 813-833). It is a compilation from Greek and Indian sources of the ninth century. Poisons are discussed and how 


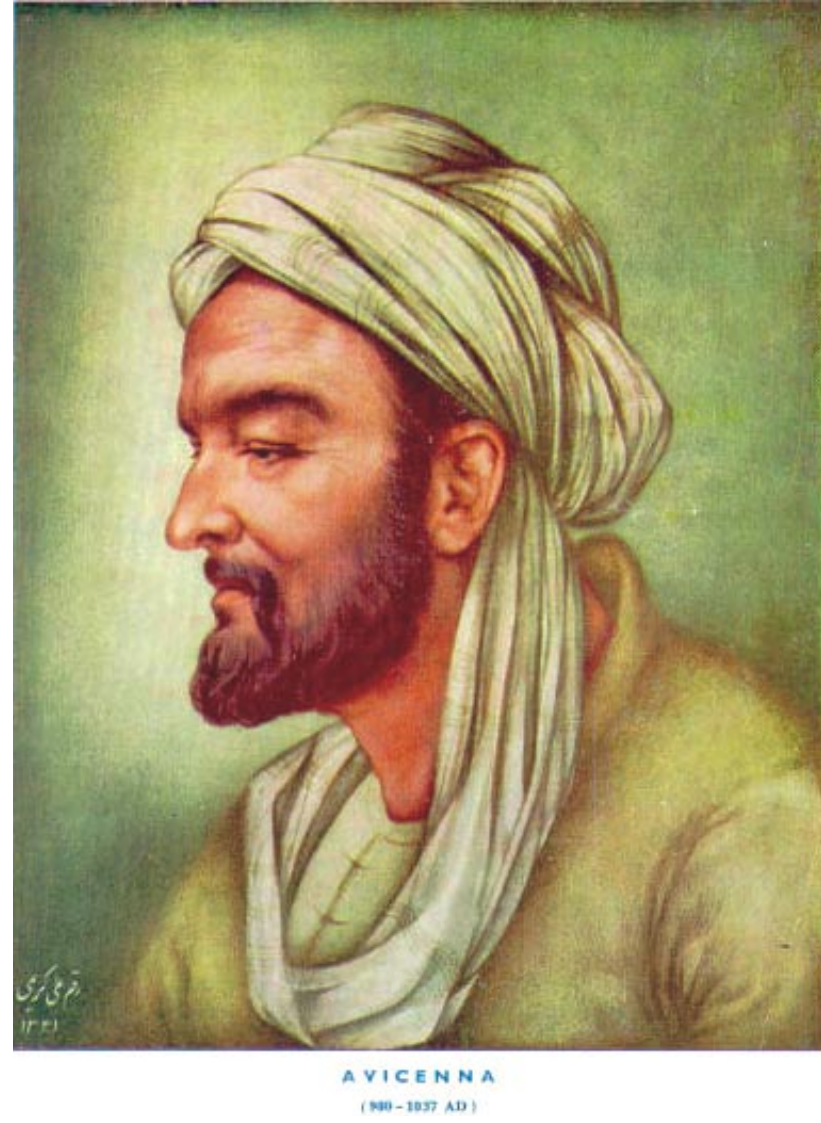

Ibn Sina (Avicenna, 980-1037) wrote many books on a wide range of topics including philosophy, mathematics and astronomy. He is perhaps most famous for his 'Laws of Medicine' which contained sections on the formulation of medicines, diagnosis of disorders, general medicine and detailed therapies. It was translated into Latin and influenced the development of medicine for several centuries.

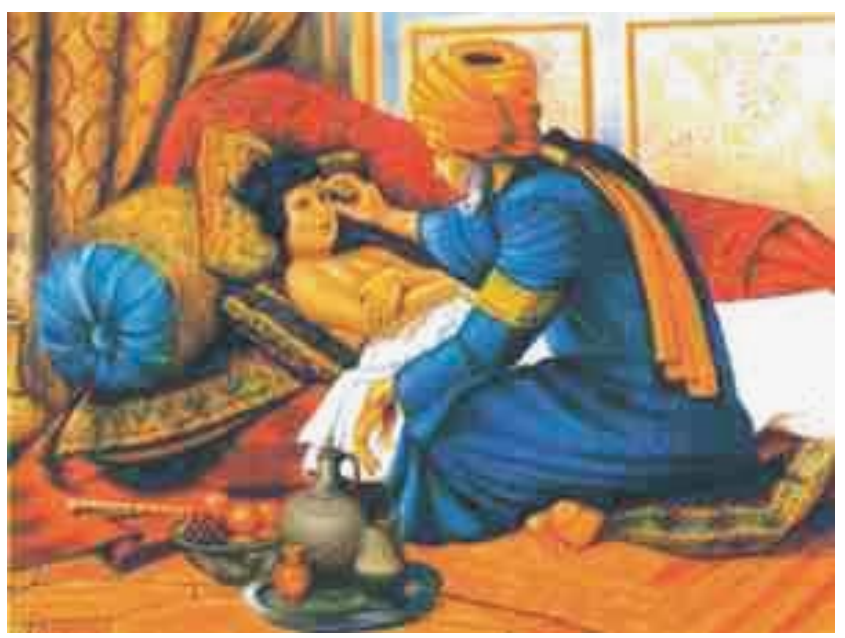

Rhazes (860-930), a Persian physician. He was chief physician at the Baghdad hospital. An observant clinician he formulated the first known description of smallpox as distinguished from measles in a work known as Liber de pestilentia. His works were widely circulated in Arabic and Greek versions and were published in Latin in the fifteenth century. They include a textbook of medicine called Almansor and an encyclopedia of medicine compiled post-humously from his papers and known as Liber continens. they can be detected by sight, touch, taste or by the toxic symptoms which they cause. Descriptions are given for poisoned drinks, foods, clothes, carpets, beds, skin lotions and eye salves, as well as narcotics and universal antidotes. A similar approach and information can be found in a later book on toxicology by Ibn Wahshiyyah during the early 900 s. Another, equally important example is the book on 'Poisons and their Antidotes' by the famous Arab alchemist, Abu Musa Jabir ben Hayyan. In its six chapters, the author identifies poisons by their traits and natural origins, their modes of action, dosages, methods of administration, choice of drugs and the target organ, which is attacked by each particular poison, a proposition that is modern in its chemotherapeutic application. He also discusses general human anatomy, the four humors and how they are affected by purgatives and lethal drugs, warns against poisonous or poisoned matter, and prescribes antidotes. His discussion of body principles and subordinate organs and their function is similar to the previously mentioned Greek classification. Many of the antidotes described by Arab scientists like Abu Musa Jabir ben Hayyan, Ibn Wahshiyyah and Avicenna are still used nowadays by herbalists in our region $(14,15)$.

\section{Efficacy of Herbal Remedies}

Arabs in the Baghdad region were the first in history (during the eighth century) to separate medicine from pharmacological science. At that point, patients started to deal with experts in the pharmaceutical sciences working on the extraction and preparation of remedies, and not with physicians who were now responsible for the diagnosis of diseases and follow-up with the applied treatments. This fact resulted in a huge development in pharmaceutical science; pharmacologists and ethnopharmacologists started to search for different ingredients and extracts to be used as remedies, and they even started to study the chemical properties of the materials used in the treatment of various diseases and ailments. For the first time, chemists such as Jaber Bin Hayan started to search for methods to extract and purify different compounds such as alcohol, nitric acids, sulfuric acids and royal acid, which was used to dissolve gold $(8,9,16)$. In the tenth century, the well-known physician Abu Bakr Rhazes (846-930 AC) started to use animals in the lab in order to test the safety and efficacy of the extracted active ingredients. The first animal used in these experiments to test the effects of mercury on the human body was a monkey $(9,10)$.

\section{A State-of-the-Art of Traditional Arab Herbal Medicine}

Despite all the marvelous advancements in modern medicine, traditional herbal medicine has always been practiced. Cultural beliefs and practices often lead to self-care or home remedies in rural areas and consultation with traditional healers. Alternative therapies have been utilized by people in our region who have faith in spiritual healers. The Mediterranean region has a very rich tradition in the use of medicinal plants for treating various ailments. In contrast to the above-mentioned historical 
Table 1. Local medicinal herbs and their uses to treat various diseases according to Arab medicine

\begin{tabular}{|c|c|c|}
\hline Disease & Number of plants used & Examples \\
\hline Skin diseases & 40 & Alchemilla vulgaris, Anchusa strigosa, Calotropis procera \\
\hline Kidney and urinary system & 27 & Ammi visnaga, Brassica napus, Glycyrrhiza glabra \\
\hline Diabetes & 26 & Achillea millefolium, Allium cepa, Allium cepa \\
\hline Digestive system & 23 & Ceratonia siliqua, Foeniculum vulgare, Micromeria myrtifolia \\
\hline Liver disease & 22 & Allium cepa, Asparagus officinalis, Cynara scolymus \\
\hline Respiratory system & 16 & Anchusa strigosa, Anchusa strigosa, Brassica oleracea \\
\hline Cancer & 13 & Allium cepa, Arum palaestinum, Brassica oleracea \\
\hline
\end{tabular}

Herbs that are used for medicinal purposes come in a variety of forms. Used parts may include leaves, flowers, stems, roots, seeds and berries.

importance of Arab medicine, research into the different modalities of complementary and alternative medicine in our region is relatively small and the current status of the knowhow of Arab herbalists is limited (14,15). The number of scientifically well-oriented and experienced herbalists is few, but there are many who have found a prosperous trade, dealing with herbal medicine without a proper background. Research into the traditional medicinal herbs still in use has also been conducted in other Arab countries such as Syria, Morocco, Yemen, Egypt and others (17-20). According to recent surveys, the Middle Eastern region is covered with more than 2600 plant species of which more than 700 are noted for their use as medicinal herbs or as botanical pesticides. Currently, fewer than 200-250 plant species are still in use in Arab traditional medicine for the treatment of various diseases $(15,21-$ 23) (Table 1). The number of herbal-derived substances that are in use as traditional compounds is about 286 (22). The most recent survey conducted on the potential uses of plant species from the coastal Mediterranean region in Egypt (20) recorded 230 species belonging to eight families. Medicinal plants in the Middle East are becoming increasingly rare due to both the ongoing destruction of their natural habitat as well as the overharvesting of wild species and detrimental climatic and environmental changes. As a result, it is predicted that in semiarid regions such as the Middle East, a number of species will disappear within the next 10 years, particularly in the desert or dry areas where almost a third of native plants are found, unless urgent measures are taken to protect and preserve them. This is paradoxical at a time when there is an increasing interest worldwide in herbal medicines accompanied by increased laboratory investigation into the pharmacological properties of the bioactive ingredients and their ability to treat various diseases (24-26).

\section{Concluding Remarks}

Historical and current studies and surveys indicate that the Eastern region of the Mediterranean have been distinguished throughout generations with a rich inventory of natural medicinal herbs. Traditional Arab medicine in our region is actually the ancient Hippocratic-Greek method, as it was adapted and improved by Arab herbalists, pharmacologists, chemists and physicians in the Middle Ages. By expanding upon the wisdom of the Greeks over the centuries, indigenous Arab medicine has contributed greatly to the development of modern medicine in Europe and remains one of the closest forms of original European medicine. Indigenous Arab medicine is well documented in old traditional texts, and some of the practitioners have such texts and make use of them to complement their experiential knowledge. Overall, when herbs are prescribed appropriately, the safety of traditional herbal medications is high. It is generally recognized that lifethreatening events in cases of using herbs to treat human diseases are rare compared with the hundreds of thousands of reports for pharmaceutical products each year. However, any plant parts used or prescribed by ethnopharmacologists should be tested for safety before being recommended for human use.

Urgent measures must be undertaken in order to protect medicinal plants in our region from the ongoing destruction of their natural habitat as well as to the overharvesting of wild species and detrimental climatic and environmental changes. In addition, urgent measures have to be undertaken to preserve the traditional knowledge about medicinal plants. Based on the information obtained from various studies, the status of knowledge concerning safety and efficacy of medicinal plants used in our region indicates that the occupation of traditional healer is a family matter and passed on by inheritance so when the present generation of healers die, the know-how may die with it. Moreover, most practitioners have very limited knowledge in the identification of species and procedures for preparing medicinal remedies. In addition, many practitioners are turning to 'mystical' or 'magical' methods of healing. This indicates a loss of the rich knowledge of practical plant medicine. Concerning the toxicity of herbal formulations safety, quality assurances and chemical analytical techniques should be applied at different stages for good practices in quality assurances of natural or herbal products, including good agricultural practice by the farmers, good sourcing and laboratory practices by the pharmaceutical companies, good manufacturing practices and innovative clinical trial practices by researchers and physicians We believe that any plant herb or ingredients taken from plants should be tested before being used as a remedy. Therefore, various advanced cell biological, biochemical, molecular biological and in vitro cell culture techniques are applied $(27,28)$. 


\section{Acknowledgment}

The authors would like to thank Ms Susan Barhoum from the Galilee Society, ShefaAmr, Israel for her constructive comments.

\section{References}

1. Cooper EL. Drug discovery, CAM and natural products. Evid Based Complement Altern Med 2004;1:215-7.

2. Cooper EL. CAM, eCAM, bioprospecting: the 21st century pyramid. Evid Based Complement Altern Med 2005;2:125-7.

3. Tsao JCI, Zeltzer LK. Complementary and alternative medicine approaches for pediatric pain: a review of the state-of-the-science. Evid Based Complement Altern Med 2005;2:149-59.

4. Solecki R. Shanidar IV, a Neanderthal flower burial in Northern Iraq. Science 1975;190:880-1.

5. Bensky D, Gamble A. Chinese Herbal Medicine: Materia Medica, Revised edition. Seattle, WA: Eastland Press, Inc., 1993, 13-7.

6. Farnsworth NR, Morris RW. Higher plants-the sleeping giant of drug development. Am J Pharm Sci Support Public Health 1976;148: 46-52.

7. Bacher W. Scham als Name Palastinas. Jew Q Rev 1906;18:564-5.

8. Bin Murad I. Research into the history of the medicine and pharmacology of the Arabs. Beirut, Lebanon: Dar AlGarb AlIslami, 1991 (in Arabic).

9. Hunke S. Shams Al Arab Tastaa Ala AlGharb (The Arab Sun is Shining on the West). Translated from German to Arabic in 1991. Casablanca (Morocco): Dar Alafak AlJadedah, 1962.

10. Rhazes . AlHawy (The Comprehensive). Beirut, Lebanon: Dar AlKalam Publishing, 925 (in Arabic).

11. Avicenna AH. AlKanoon Fi Altib (The Rules of Medicine). Four Volumes, Printed in 1993. Beirut, Lebanon: Iz Aldin Publications, 1037 (in Arabic).

12. Shams Aldeen A. Altadawy Fi Alashaab Kademan wa Hadethan (Healing with Herbs in the Past and Present). Beirut, Lebanon: Dar AlKutum Alelmeah, 1991 (in Arabic)

13. Munke L. AlTadawy Be Alashab Fi Masr Alkademeh (Healing with Herbs in Old Egypt). Cairo, Egypt: Maktabat Madbouly, 1993 (in Arabic).

14. Shaikh BT, Hatcher J. Complementary and alternative medicine in Pakistan: prospects and limitations. Evid Based Complement Altern Med 2005;2:139-42.

15. Said O, Khalil K, Fulder S, Azaizeh H. Ethnopharmacological survey of medicinal herbs in Israel, the Golan Heights and the West Bank region. J Ethnopharmacol 2002;83:251-65.
16. AlTurkimany JOA. AlMoatamad Fi Aladweah Almofradah (The source of the single Pharmaceuticals). Revised by AlSaka M. Beirut, Lebanon: Dar AlKalam Publishing, 1993 (in Arabic).

17. Ahmed MS, Honda G, Miki W. Herb Drugs and Herbalists in the Middle East, Tokyo, Japan. 1979;8.

18. Honda G, Miki W, Saito M. Herb drugs and herbalists in Syria and North Yemen. Studia culturae Islamicae 1990;39.

19. Eddouks M, Maghrani M, Lemhadri A, Ouahidi ML, Jouad H. Ethnopharmacological survey of medicinal plants used for the treatment of diabetes mellitus, hypertension and cardiac diseases in the south-east region of Morocco (Tafilalet). J Ethnopharmacol 2002;82: 97-103.

20. Heneidy SZ, Bidak LM. Potential uses of plant species of the coastal Mediterranean region, Egypt. Pak J Biol Sci 2004;7:1010-23.

21. Lev E, Amar Z. Ethnopharmacological survey of traditional drugs sold in Israel at the end of the 20th century. J Ethnopharmacol 2000;72: 191-205.

22. Lev E, Amar Z. Ethnopharmacological survey of traditional drugs sold in the Kingdom of Jordan. J Ethnopharmacol 2002;82:131-45.

23. Azaizeh H, Fulder S, Khalil K, Said O. Ethnobotanical survey of local practitioners of the Middle Eastern region: the status of traditional Arabic medicine. Fitoterapia 2003;74:98-108.

24. Cooper EL. Complementary and alternative medicine, when rigorous, can be science. Evid Based Complement Altern Med 2004;1:1-4.

25. Müller WEG, Batel R, Schröder HC, Müller IM. Traditional and modern biomedical prospecting: Part I-the history. Sustainable exploitation of biodiversity (sponges and invertebrates) in the Adriatic Sea at Rovinj (Croatia). Evid Based Complement Altern Med 2004;1:71-82.

26. Mueller WEG, Schroder HC, Wiens M, Perovic-Ottstadt S, Batel R, Muller IM. Traditional and modern biomedical prospecting: Part II-the benefits. Approaches for a sustainable exploitation of biodiversity (secondary metabolites and biomaterials from sponges). Evid Based Complement Altern Med 2004;1:133-44.

27. Saad B, Abu-Hijleh G, Suter UW. Cell culture techniques for assessing tissue compatibility of biomaterials. In: Arshady R (ed). Polymers in Medicine and Biotechnology, Volume 1. Polymer Chemistry and Biodegradation, Citus Books, 2003, 263-99.

28. Saad B, Dakwar S, Said O, Abu-Hijleh G, Al Battah F, Kmeel AS, Aziazeh H. Evaluation of medicinal plants hepatotoxicity in co-cultures of hepatocytes and monocytes. eCAM 2005 (in press).

29. Ibn AlBitar, DAM. AlJame Li-Mofradat al Adwiyah wal Aghthiyah (The collection of Medical and Food Items). Two Volumes. Dar Sader Publishing, Beirut, Lebanon (in Arabic), 1874.

Received August 29, 2005; accepted September 26, 2005 


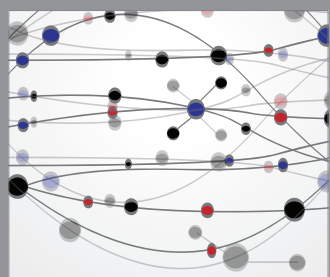

The Scientific World Journal
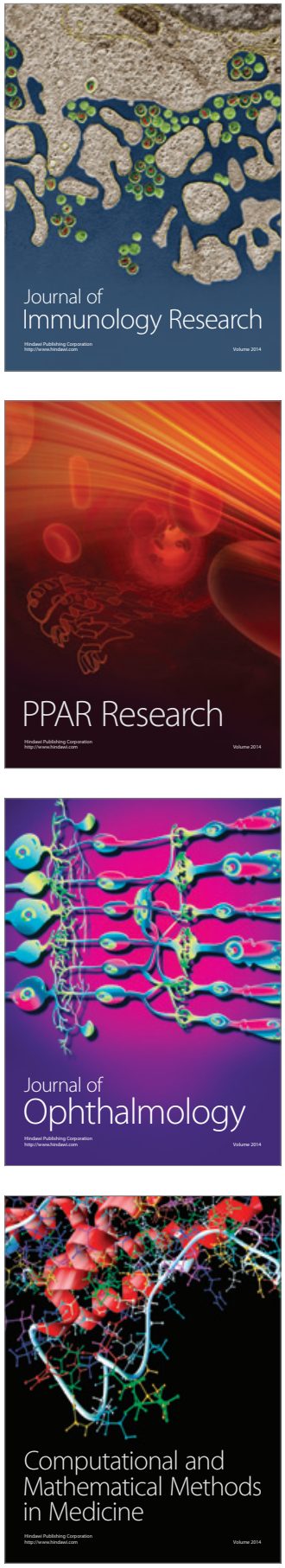

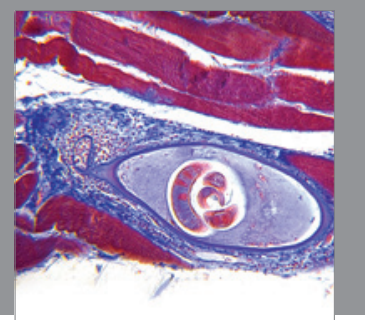

Gastroenterology

Research and Practice
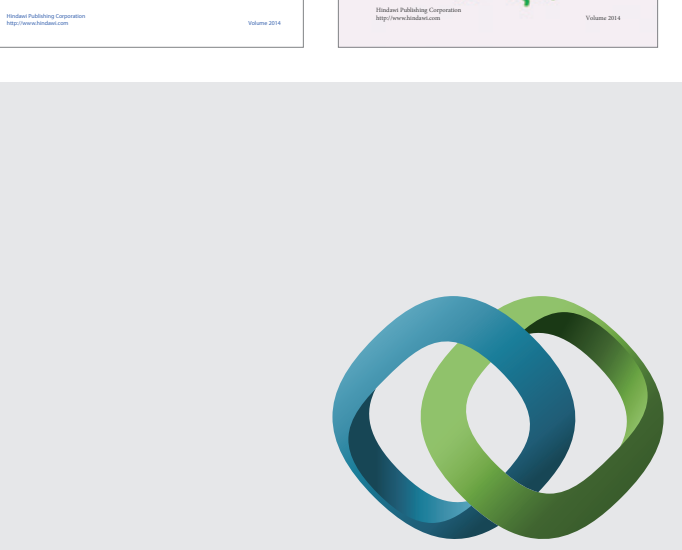

\section{Hindawi}

Submit your manuscripts at

http://www.hindawi.com
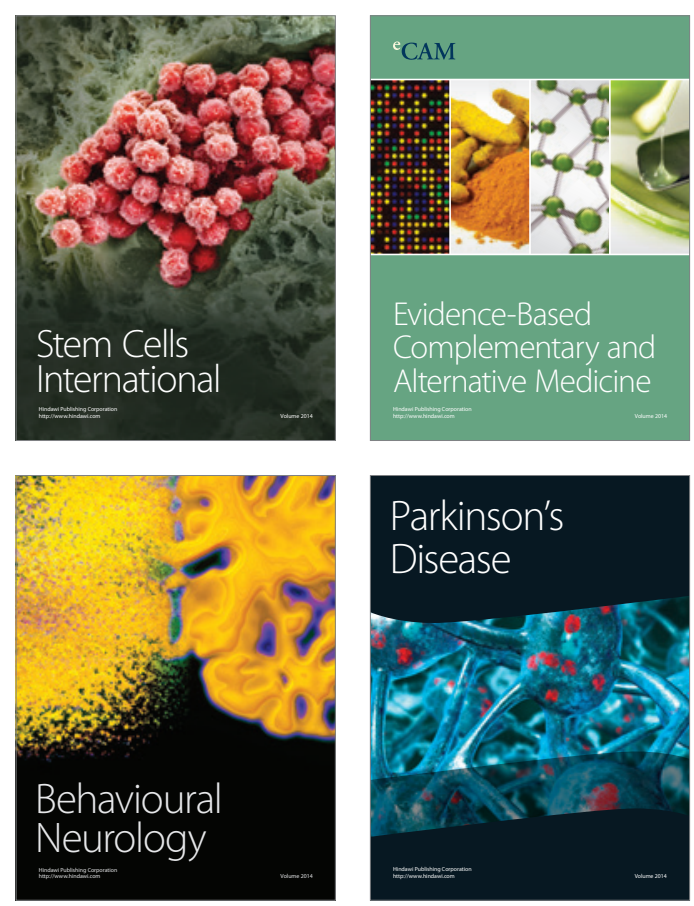

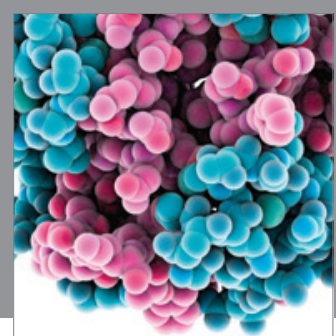

Journal of
Diabetes Research

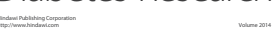

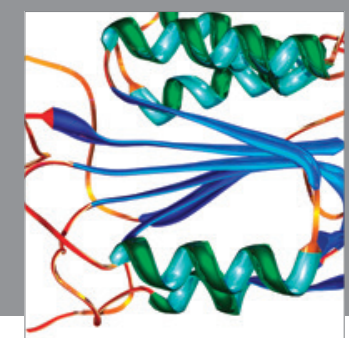

Disease Markers
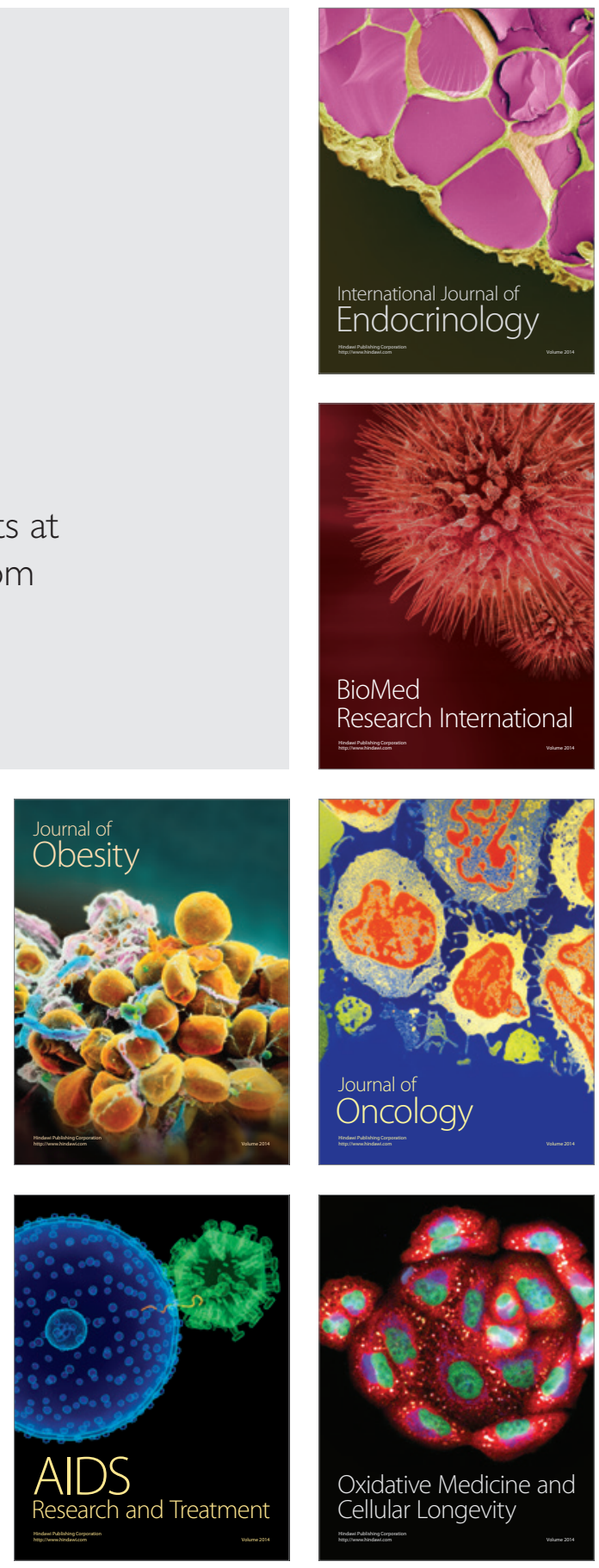